\title{
Variability of fat content and fatty acids profiles in seeds of a Polish white lupin (Lupinus albus L.) collection
}

\author{
Wojciech Rybiński • Wojciech Święcicki • Jan Bocianowski • Andreas Börner • \\ Elżbieta Starzycka-Korbas • Michał Starzycki
}

Received: 9 January 2017 / Accepted: 27 June 2017/ Published online: 6 July 2017

(C) The Author(s) 2017. This article is an open access publication

\begin{abstract}
The paper assess the variability of fat content and fatty acids profiles in seeds of a white lupin (Lupinus albus L.) domestic collection. The initial material comprised 371 accessions originated from 30 countries of Europe, Asia, Africa, North- and South America and Australia. According to data given by accession donors the material is divided into four classes of origin: wild lines, landraces, lines created by man and cultivars. Variability of fat content and fatty acids composition were estimated in seeds of each accession. The average fat content for analyzed collection is $9.81 \%$. The broadest range of fat content was noticed for landraces and cultivars as compared to narrowest represented by lines created by man. Fat content ranged from $6.9 \%$ (induced mutant Wt 95497) to $14.1 \%$ (Polish
\end{abstract}

W. Rybiński · W. Święcicki

Institute of Plant Genetics, Polish Academy of Sciences,

Strzeszyńska 34, 60-479 Poznań, Poland

J. Bocianowski $(\bowtie)$

Department of Mathematical and Statistical Methods,

Poznań University of Life Sciences, Wojska Polskiego 28, 60-637 Poznań, Poland

e-mail: jboc@up.poznan.pl

\section{A. Börner}

Leibniz Institute of Plant Genetics and Crop Plant

Research, 06466 Gatersleben, Germany

E. Starzycka-Korbas · M. Starzycki

Department of Oil Plants, Institute of Plant Breeding and Acclimatization, Strzeszyńska 36, 60-479 Poznań, Poland cultivar Wt 95420 and the landrace Wt 95212 from Jordan). From a dietetic point of view, oil quality is more important than oil quantity in lupin seeds. On average the fatty acid (FA) in examined accessions ranked in following order of abundance: oleic acid $\left(\mathrm{C}_{18: 1}\right)>$ linoleic acid $\left(\mathrm{C}_{18: 2}\right)>$ linolenic acid $\left(\mathrm{C}_{18: 3}\right)>$ palmitic acid $\left(\mathrm{C}_{16: 0}\right)>$ eicosenoic acid $\left(\mathrm{C}_{20: 1}\right)>$ stearic acid $\left(\mathrm{C}_{18: 0}\right) \approx$ erucic acid $\left(\mathrm{C}_{22: 1}\right)$. In respect to unsaturated fatty acid (UFA), monounsaturated oleic acid in each of estimated classes of accessions was predominant and most abundant (55.7\%) in broad range of minimummaximum values from 41.2 to $66.2 \%$. The second examined monounsaturated fatty acid was erucic acid $(1.74 \%)$ found in seeds of almost all studied accessions. An exception were four accessions defined similarly to rapeseeds as "zero erucic" forms. In seeds of few accessions a content of erucic acid exceeded $3 \%$. Among polyunsaturated fatty acids linoleic FA $(\omega-6)$ dominated followed by linolenic FA $(\omega-3)$. Both FA were in the range $13.7-33.2 \%$ and $5.6-12.8 \%$ with mean values on the level 19.6 and $10.1 \%$, respectively. As a consequence, the examined white lupin seeds showed a very favourable $\omega-3 / \omega-6$ FA ratio (0.51), ranging from 0.21 to 0.87 , much higher than that of most vegetable oils. Fat content was positively correlated with stearic and oleic fatty acids and negatively with palmitic, linoleic, linolenic and erucic acid.

Keywords Genetic resources valorization - Fat . Fatty acids $\cdot$ Lupinus albus $\cdot$ Multivariate statistical analysis · White lupin seeds 


\section{Introduction}

Lupins are economically and agriculturally valuable crops (Sujak et al. 2006; Gulewicz et al. 2008; Kohajdova et al. 2011) and together with others legumes are a main source of protein in human diet. The are also rich in dietary fibre and carbohydrates (Rochfort and Panozzo 2007). The genus Lupinus covers about 275 species but only four (L. angustifolius L., L. luteus L., L. albus L., L. mutabilis Sweet) are used in agriculture on larger scale (Reinhard et al. 2006; Mülayim et al. 2002, Święcicki et al. 2015). Consumption of lupin seeds has increased in recent years (De Cortes-Sanchez et al. 2005; Święcicki et al. 2015) as alkaloids were removed from seeds by debittering or breeding sweet cultivars with highly valuable seed protein and dietary fibre (Cowling et al. 1998; Gladstones 1998; Petterson 1998; El-Adawy et al. 2001; Święcicki et al. 2015) as well as low level of antinutritional factors such as phytases, protease inhibitors and lectins (Cowling et al. 1998).

White lupin (L. albus) has the longest history in human consumption, dating back to pre-Roman times (Gladstones 1970; Hondelmann 1984). It was the only lupin cultivated in the Ancient Greece. Its large seeds, well soaked, strongly salted seasoned with vinegar and vegetable oil, were served as food for human. Lupinus albus L. originates from South-Eastern Europe and Western Asia where wild types still occur (Gladstones 1970). Actually white lupin is a crop grown around the Mediterranean and Black Sea and in the Nile valley extending to Sudan and Ethiopia as well as occasionally in South Africa and both Americas (Jansen 2006). However, it is characterized by such valuable traits as the high protein, fat content and seed yield it still belongs to minor pulse crops. A radical increase of white lupin acreage depend on a substantial shortening of vegetation and improving the resistance to antracnose (Święcicki et al. 2015). For the white lupin as high protein crop the main attention is particularly focused on protein quality (the amino acid profile), however much less attention is focused on the content and quality of oil (Suchy et al. 2008; Rybiński et al. 2013). Some species have considerable amount of oil in its seed (Uzun et al. 2007; Kohajdova et al. 2011). It is particularly true for Andean lupin with oil content on the level 16-20\% (Święcicki et al. 2015). Lower content have seeds of white lupin (9.76-12.1\%) but higher as compared to narrow-leafed and yellow lupin
-6.5 and $5.1 \%$ as well as to field pea and grass pea -1.6 and $1.1 \%$, respectively (Rybiński et al. 2014). Oil is present particularly in cotyledons, $95-98 \%$ of total content (Smulikowska et al. 1995). From a dietetic point of view more important as quantity is the quality of oil. Generally, the quality of fat depends on fatty acid profile and content, and the ratios between individual acids. Unsaturated fatty acids, particularly polyunsaturated fatty acids (PUFA), are essential nutrients and the $\omega-3 / \omega-6$ ratio is considered as very important with respect to human and animal feeding (Suchy et al. 2008). In general, lupin oil is characterized by balanced fatty acid composition with total saturated fatty acids of $10 \%$ and total unsaturated fatty acids of 90\% (Bhardwaj et al. 1998; Hamma and Bhardwaj 2004; Kohajdova et al. 2011).

The success of white lupin improvement programme largely depends on the wealth of the genetic resources. In presented studies, the variability of fat content and fatty acids profiles were estimated in seeds of the Polish collection of white lupin.

\section{Materials and methods}

The material included 371 accessions of white lupin originated from Polish Lupinus Gene Bank located at Wiatrowo (Poznań Plant Breeders Ltd). Majority of investigated material originates from Mediterranean area (Spain, Greece, Portugal and Italy) and Poland. According to data given by accessions donors the material was divided in four classes of origin: 180 wild lines and primitive populations originating from places of distributions and collecting missions (CO), 75 landraces (LR), and 54 lines created by man as a result of selection after crossings or mutation induction for different aims (XD) as well as 62 cultivars $(\mathrm{CV})$. For analysis of fat and fatty acids profiles the uniform samples of seeds were used from field trial located in breeding station at Wiatrowo (Poland), 2014 (completely randomized design, two replications, plot size $1 \mathrm{~m}^{2}, 60$ seeds per plot).

Soxhlet analysis was performed in order to quantify seed oil. Inside the thimble, made of thick paper, particulate material was placed (10 $\mathrm{g}$ of seed) and then extracted $12 \mathrm{~h}$ in Soxhlet extractor with n-hexane. Samples were weightted after extraction and the loss of fat, indicate the percentage of its participation. Composition of fatty acids was determined using the 
Hewlett Packard gas chromatograph (GC), Agillent Technologies $6890 \mathrm{~N}$ Network GC System. Fat extraction and esterification of methyl esters of fatty acids and quantitative estimates of chromatograms were performed. Methyl esters of fatty acids were separated using a DB-23 capillary column. Hydrogen was used as carrier gas for GC analysis. The temperature of the chromatography column was $200{ }^{\circ} \mathrm{C}$ and a detector $220{ }^{\circ} \mathrm{C}$. Chromatographic separation of analyzed compounds lasted $10 \mathrm{~min}$. The Chemistation program was used to calculate the percentage of each fatty acid. As a result of a chromatograph usage following fatty acids were estimated: palmitic $\left(\mathrm{C}_{16: 0}\right)$, stearic $\left(\mathrm{C}_{18: 0}\right)$, oleic $\left(\mathrm{C}_{18: 1}\right)$, linoleic $\left(\mathrm{C}_{18: 2}\right)$ linolenic $\left(C_{18: 3}\right)$, eicosenoic $\left(C_{20: 1}\right)$ and erucic $\left(C_{22: 1}\right)$. The percentage values of the considered groups of fatty acids (FA) were obtained from summation of the percentage of appropriate FA: SFA, sum of percentage values of total saturated FA, i.e., palmitic acid + stearic acid; MUFA, sum of the percentage values of monounsaturated FA, i.e., oleic acid + eicosenoic acid + erucic acid; PUFA, sum of the percentage values of polyunsaturated FA, i.e., linoleic acid + linolenic acid. Ratio $\omega-3 / \omega-6$ was expressed as the ratio linolenic acid/linoleic acid.

Firstly, the normality of distribution of the traits was tested using Shapiro-Wilk's normality test. Oneway analysis of variance (ANOVA) was carried out to determine the effects of accessions on the variability of observed traits. When critical differences were noted, multiple comparisons were carried out, using Tukey's least significant differences (LSDs) for each trait. Based on this, homogeneous groups (not significantly different from each other) were determined for analyzed traits. The means, minimum, maximum and standard deviation for each trait were calculated. The Pearson correlation coefficients were calculated for all traits. Principal component analysis (PCA) was then performed on all traits. Analysis of the data was performed using the statistical package GenStat v. 17 .

\section{Results and discussion}

Fat content and fatty acid composition

The accessions belonging to four classes of origin were included in performed analysis of variance. All accessions under estimation (excluding stearic, oleic and linolenic acid) differed significantly with relation to remaining features at the level 0.01 and 0.001 (Table 1). Results of fat content in seeds are present in Table 2 and in form of boxplot in Fig. 1. The average fat content for 371 white lupin accessions is $9.81 \%$. This value is markedly higher as compared to field pea, grass pea, common vetch and lentil $(2.2,1.5,1.3$ and $2.6 \%$, respectively), higher as compared to narrow-leafed and yellow lupins $(6.8 \%)$ and lower in comparison to Andean lupin (14.9\%) (Rybiński et al. 2015). Fat in lupin is located in embryos but $90 \%$ of total content is observed in cotyledons (Francki et al. 2002). Their content can be affected by a genotype within the same species (Uzun et al. 2007) as well as by environmental factors during plant growth and development (temperature, air moisture, rainfalls level) and seed storage (Boschin et al., 2007, 2008; Adomas and Piotrowicz-Cieślak 2010; Nigussie 2012). Boschin et al. (2008) in the field trial with six white lupin cultivars in two locations indicated, that variance of genotypic effects was much larger than genotype-environment interaction for oil content and fatty acid composition. Above mentioned factors can explain differentiated results of fat content in seed of white lupin $(5.9,7.6,8.9,9.4,9.6,9.7,10.7,10.9$ and $14.6 \%$ obtained by following authors respectively: Erbas et al. 2005; Roth-Maier and Kirchgessner 1993; Tizazu and Emire 2010; Petterson et al. 1997; Green and Oram 1983; Jansen 2006; Uzun et al. 2007; Rybinski et al. 2015; Martinez-Villaluenga et al. 2006). It was also shown for yellow lupin that seed

Table 1 Mean squares from one-way analysis of variance (ANOVA) for investigated traits of studied accessions

\begin{tabular}{lll}
\hline Source of variation & Accessions & Residual \\
\hline Number of degrees of freedom & 3 & 367 \\
Fat (oil) & $12.498^{* * *}$ & 1.394 \\
Palmitic acid $\left(\mathrm{C}_{16: 0}\right)$ & $6.7791^{* * *}$ & 0.3316 \\
Stearic acid $\left(\mathrm{C}_{18: 0}\right)$ & $0.3296^{\mathrm{ns}}$ & 0.1591 \\
Oleic acid $\left(\mathrm{C}_{18: 1}\right)$ & $1.542^{\mathrm{ns}}$ & 9.834 \\
Linoleic acid $\left(\mathrm{C}_{18: 2}\right)$ & $35.352^{* *}$ & 6.801 \\
Linolenic acid $\left(\mathrm{C}_{18: 3}\right)$ & $1.768^{\mathrm{ns}}$ & 1.303 \\
Eikosenoic acid $\left(\mathrm{C}_{20: 1}\right)$ & $2.9124 * * *$ & 0.4166 \\
Erucic acid $\left(\mathrm{C}_{22: 1}\right)$ & $2.1946^{* * *}$ & 0.3183 \\
$\omega-3 / \omega-6$ fatty acid ratio & $0.0441^{* * *}$ & 0.0063 \\
\hline
\end{tabular}

$n s$ not significant

** $P<0.01, * * * P<0.001$ 
Table 2 Fat content (g/100 g d.m.) in seeds of white lupin accessions

\begin{tabular}{lclll}
\hline Accessions & Mean & Minimum & Maximum & SD \\
\hline CO & $10.077 \mathrm{a}$ & 7.1 & 12.9 & 1.117 \\
LR & $10.227 \mathrm{a}$ & 7.6 & 14.1 & 1.331 \\
XD & $9.287 \mathrm{c}$ & 6.9 & 11.2 & 0.854 \\
CV & $9.655 \mathrm{~b}$ & 7.1 & 14.1 & 1.393 \\
LSD $_{0.05}$ & 0.36 & & & \\
\hline
\end{tabular}

$\mathrm{CO}$ —wild lines, LR—-landraces, $\mathrm{XD}$ —cross derivatives plus mutants, $\mathrm{CV}$ - cultivars

Means followed by different letter differ at $\alpha=0.05$

development was accompanied by an increase of oil content from $4.45 \%$ in 30 th day after flowering to $5.57 \%$ in 55th day after flowering (Adomas and Piotrowicz-Cieślak 2010). According to Mohamed and Rayas-Duarte (1995) seeds of different lupin species contain approximately 5-20\% of crude oil but from $7.12 \%$ to $11.50 \%$ in seeds of white lupin cultivars (Boschin et al. 2008). In presented results (Table 2) fat content for 371 accessions ranged from 6.9 to $14.1 \%$. The broadest range of fat content was noticed for LR and $\mathrm{CV}$ classes as compared to narrowest represented by XD (Fig. 1). Average fat content was highest (above 10\%) for LR and CV classes however differences among four studied classes were not great. For 550 white lupin accessions growing in Ukraine (Kiev province) average fat content $(9.5 \%)$ was similar to our but with narrower range of variability (6.2-11.5\%). Cultivars and accessions from Russia, Spain, Poland and Palestine showed increased oil content (9.5\% on average and higher), while accessions from Italy and Ethiopia demonstrated reduced amount of oil $(<9 \%)$ (Kurlovich 2002).

Generally, the quality of fat depends on fatty acid (FA) profile and content, and the ratios between individual acids. For essential nutrients belong polyunsaturated fatty acids (PUFA). For PUFA the $\omega-3 / \omega-6$ ratio (linolenic/linoleic fatty acids) is very important with respect to human and animal feeding (Suchy et al. 2008). According to results presented in Tables 3 and 4 the percent of FA in examined classes of accessions ranked in following order of abundance: oleic acid $\left(\mathrm{C}_{18: 1}\right)>$ linoleic acid $\left(\mathrm{C}_{18: 2}\right)>$ linolenic acid $\left(\mathrm{C}_{18: 3}\right)>$ palmitic acid $\left(\mathrm{C}_{16: 0}\right)>$ eicosenoic acid $\left(\mathrm{C}_{20: 1}\right)>$ stearic acid $\left(\mathrm{C}_{18: 0}\right) \approx$ erucic acid $\left(\mathrm{C}_{22: 1}\right)$. Concerning saturated fatty acids (SFA) (Table 3, Fig. 1) the average percentage of palmitic acid was in the range from $6.09 \%$ for $\mathrm{CO}$ accessions to $6.68 \%$ for accessions of XD with the broadest variation from 4.5 to $9.0 \%$ for LR accessions. Average content of palmitic acid $(6.37 \%)$ is similar to $6.21,6.79,7.2$ and $7.6 \%$ reported for white lupin by Rybiński et al. (2014), Mierlita (2015), Oomah and Bushuk (1984) and Uzun et al. (2007), respectively, but markedly lower as compared to 11.6 and $15.2-19.8 \%$ noticed by Erbas et al. (2005) and Boschin et al. (2008), respectively. No significant differences (7.8 and $7.1 \%$ ) were found between sweet and bitter white lupin (Yorgancilar and Bilgicli 2014). Average stearic acid content $(1.92 \%)$ was in the range from $1.84 \%$ for $\mathrm{CV}$ accessions to $2.02 \%$ for XD with minimum and maximum values for all accessions of 1.2 and $3.3 \%$ respectively. These results are in agreement with the values published in literature: 1.2-1.8, 1.46-1.55, 1.34-3.56 and 2.28\% (Oomah and Bushuk 1984; Bhardwaj and Hamma 2013; Boschin et al. 2008; Zraly et al. 2007, respectively). In respect to unsaturated fatty acid (UFA), oleic acid as member of monounsaturated FA (MUFA) was predominant and most abundant FA, with the average content falling in the very narrow range from $55.65 \%$ for XD to $55.93 \%$ for CO accessions (Table 4; Fig. 1). Values of minimum and maximum for all examined accessions (41.2\% for LR from Egypt and $66.2 \%$ for CO from Israel) indicate a broad variation of this trait in white lupin seeds. According to data given by Oomah and Bushuk (1984) average content of oleic acid for three cultivars of white lupin (51.9, 55.5 and $54.2 \%)$ were on the same mean level as our results and comparable in the range: $43.6-54.4,40.8-50.5$ and $36.2-49.61 \%$ reported, by Green and Oram (1983), Boschin et al. (2008) and Mierlita (2015), respectively. Presented mean content of oleic acid $(55.7 \%)$ is higher as compared to narrow-leafed lupin (39.4\%), yellow lupin (29.4\%) and Andean lupin (44.8\%) (Rybiński et al. 2015) as well as in seeds of chickpea (33.5\%), lentil (22.95) and pea (28.2\%) (Ryan et al. 2007). For examined MUFA belong also eicosenoic and erucic acid with mean content of 4.53 and $1.74 \%$ respectively, and in the range $4.36-4.79 \%$ for $\mathrm{CO}$ and $\mathrm{CV}$ and $1.61-1.99 \%$ for LR and CV accessions, respectively. Literature data for eicosenoic acid content are generally similar to ours on the level of 4.60, 4.17 and 4.65\% (Oomah and Bushuk 1984; Zraly et al. 2007; Rybiński et al. 2014, respectively). Content of $C_{22: 1}$ (erucic acid) in seeds is considered undesirable for 


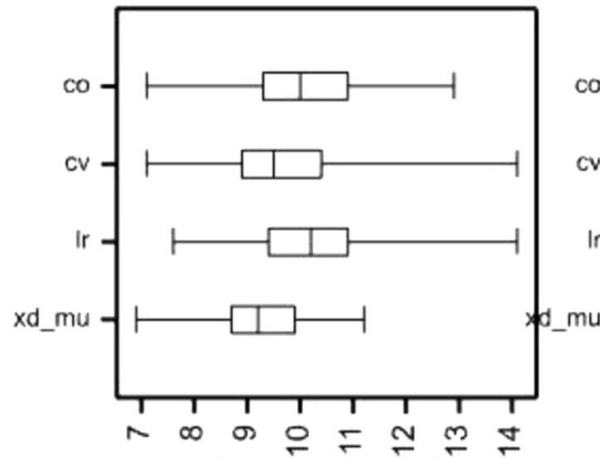

fat content $(\%)$
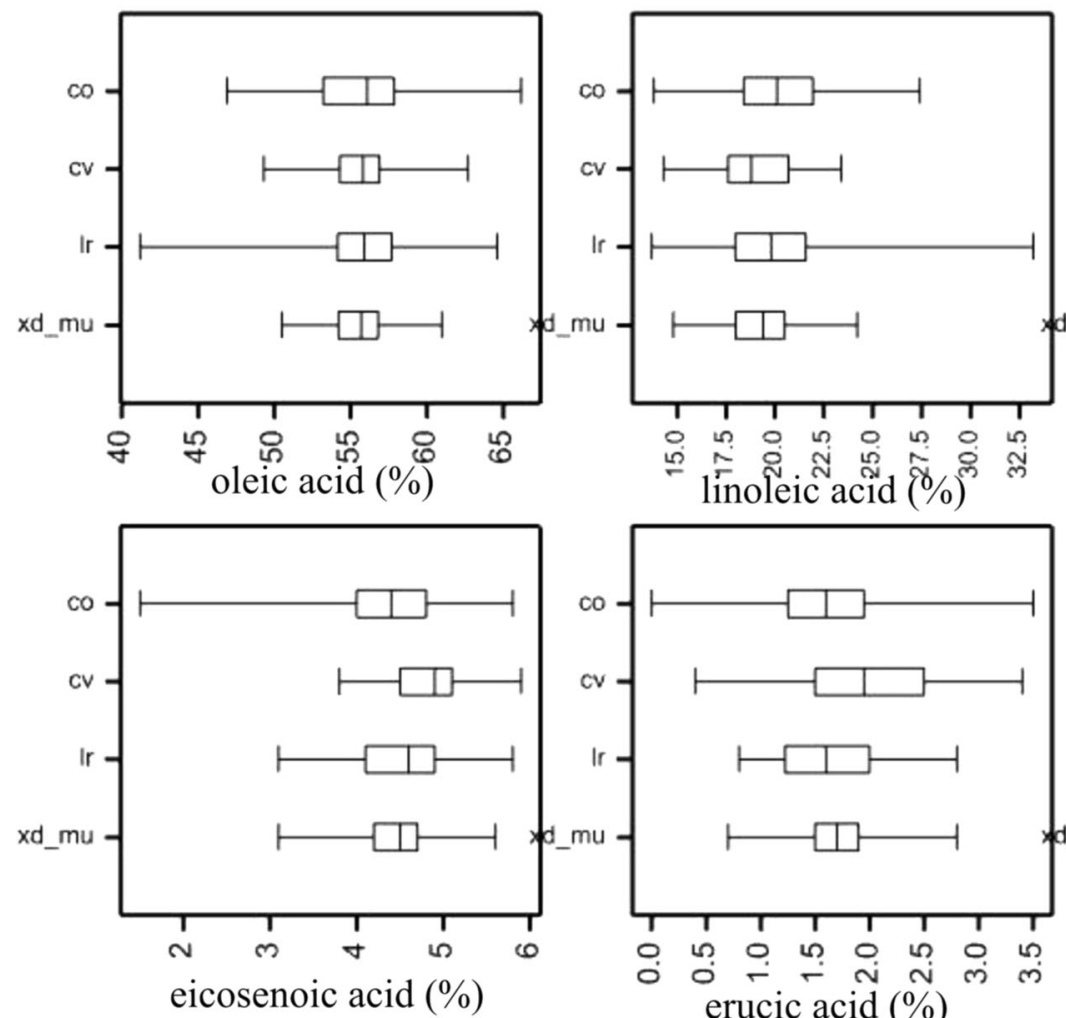

palmitic acid $(\%)$

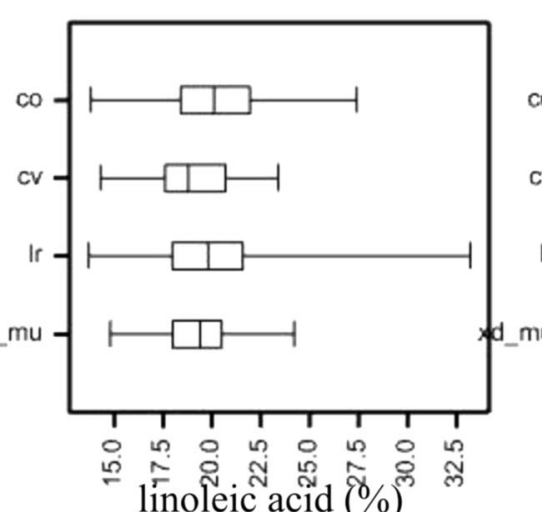

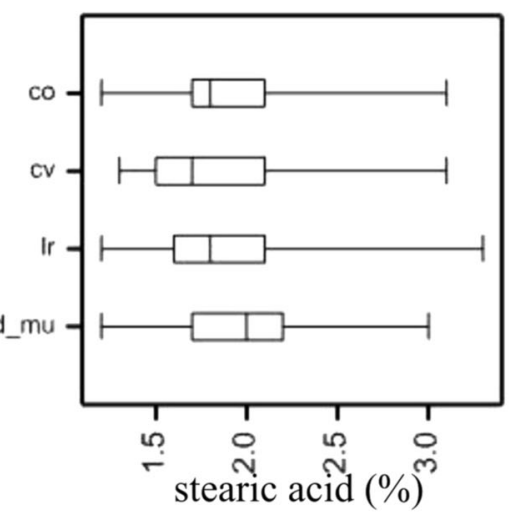
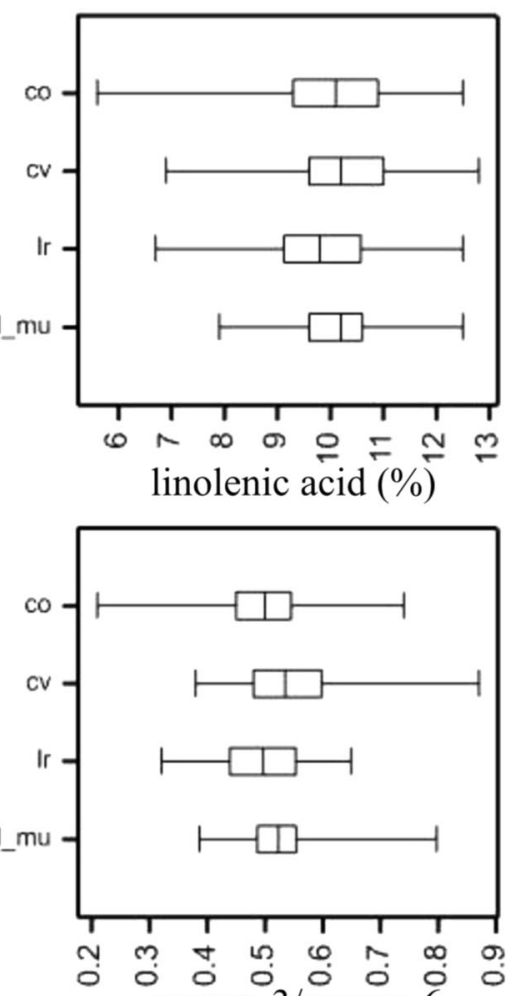

Fig. 1 Box-and-whisker diagram of values of fat (\%) and fatty acids content ( $\%$ in oil) for palmitic acid, stearic acid, oleic acid, linoleic acid, linolenic acid, eicosenoic acid and erucic acid in

seeds as well as $\omega-3 / \omega-6$ of particular types of accessions ( $\mathrm{CO}$; LR; XD; CV) listed in chapter "Material and Method" section

human nutrition (Bhardwaj and Hamma 2013). This work as well as data given by Boschin et al. (2008) indicates that a drawback of white lupin is the presence of small amounts of erucic acid (Codex Alimentarius 2001). Minimum and maximum values for erucic acid ranged from zero to $3.5 \%$ (Table 4). Among 371 white lupin accessions only four of them (one from Israel and three from Turkey found exclusively among $\mathrm{CO}$ accessions) were erucic-free. It indicates how difficult is to recognize zero erucic accessions and that the $\mathrm{CO}$ is a valuable collection material for selection purposes. It is also interesting, that all selected "zero" erucic fatty acid accessions were particularly rich in oleic acid in range from 59 to $63 \%$. A broad range of erucic acid $(0.78-4.84 \%)$ obtained by Boschin et al. (2008) allowed to recognize "low-erucic acid" cultivars. In opinion of these authors an erucic acid as a negative feature appears to be not important since 
Table 3 Saturated fatty acids (\% in oil) in fat content in white lupin represented by: wild lines (CO); landraces (LR); cross derivatives plus mutants (XD); cultivars (CV)

\begin{tabular}{lllll}
\hline Fatty acid/accessions & Mean & Minimum & Maximum & Standard deviation (SD) \\
\hline Palmitic acid $\left(\mathrm{C}_{16: 0}\right)$ & & & & \\
CO & $6.095 \mathrm{~b}$ & 4.6 & 7.8 & 0.521 \\
LR & $6.171 \mathrm{~b}$ & 4.5 & 9.0 & 0.678 \\
XD & $6.687 \mathrm{a}$ & 5.3 & 8.1 & 0.525 \\
CV & $6.545 \mathrm{a}$ & 5.1 & 7.7 & 0.632 \\
LSD & 0.176 & & & \\
Stearic acid $\left(\mathrm{C}_{18: 0}\right)$ & & & & \\
CO & $1.923 \mathrm{a}$ & 1.2 & 3.1 & 0.374 \\
LR & $1.899 \mathrm{a}$ & 1.2 & 3.3 & 0.420 \\
XD & $2.026 \mathrm{a}$ & 1.2 & 3.0 & 0.403 \\
CV & $1.845 \mathrm{a}$ & 1.3 & 3.1 & 0.435 \\
LSD & 0.151 & & & \\
\hline
\end{tabular}

lupin oil is not a commercial product. On the other hand, the selection of erucic- free or low-erucic genotypes would be certainly desirable.

Unsaturated fatty acids, particularly polyunsaturated fatty acid (PUFA) belong to essential nutrients and play an important role with respect to human and animal nutrition. Lupin oil is characterized by high dietetic quality from this point of view. Among essential fatty acids, white lupin oil contain linoleic and linolenic acid (Table 4, Fig. 1). Obtained results show that linoleic acid $(\omega-6)$ after oleic acid is a prevailing in white lupin with mean content $19.6 \%$ and in the range from $18.91 \%$ for $\mathrm{CV}$ to $20.29 \%$ for $\mathrm{CO}$ accessions. The lowest value (13.7\%) was noticed for LR from Poland and the highest $(33.2 \%)$ for LR from Egypt characterized also by the lowest (44.1\%) content of oleic acid. Presented results are generally in agreement with following values: 17.3, 18.1, 20.3, 22.4 and 22.19\%, obtained by Petterson and Mackintosh (1994), Oomah and Bushuk (1984), Uzun et al. (2007), Erbas et al. (2005) and Zraly et al. (2007), respectively. A markedly lower content of linoleic acid (7.79-15.81) indicate Boschin et al. (2008) and higher content in sweet seeds $(25.6 \%)$ versus bitter seed (18.9\%) Yorgancilar and Bilgicli (2014). Average content of linolenic acid $(10.07 \%)$ constituted a half of percentage content of linoleic acid (19.62\%). No statistic significant differences were found among examined classes of accessions (Table 4), however a broad range of variation (5.6-12.8\%) indicates on possibility of accessions selection with the high content of desired linolenic acid $(\omega-3)$. Range of minimum-maximum values showed the broadest range of variability for $\mathrm{CO}$ accessions (5.6-12.5\%) and the narrowest (7.9-12.5\%) for XD. Similar range (5.31-10.36\%) was obtained by Boschin et al. (2008). Another literature data for linolenic acid are comparable to ours [8.88\% in Mierlita (2015), 9.2\% in Uzun et al. (2007), 9.68\% in Bhardwaj (2002) and $10.2 \%$ in Oomah and Bushuk (1984)]. The content of linolenic acid in seeds of narrow-leafed lupin, yellow lupin and Andean lupin was lower: 6.2, 4.2 and 2.6\%, respectively (Petterson, 1998; Cowling and Tarr 2004) and 4.9, 8.13 and $2.86 \%$ (Rybiński et al. 2014).

Based on the results from Tables 3 and 4 the composition of respective fatty acids groups in the lipid compound of white lupin are presented in Table 5. For SFA, MUFA and PUFA no visible differences were observed among examined classes of accessions. For the most desired PUFA the highest value (above 30\%) was obtained for $\mathrm{CO}$ accessions. Prevailed is monounsaturated FA (MUFA 62\%). Polyunsaturated FA (PUFA) and saturated FA (SFA) constituted 29.7 and $8.3 \%$, respectively. Comparable ratios for white lupin (SFA:MUFA:PUFA): 12.52:52.34:35.14\% and 13.5:55.4:31.1\% were indicated by Zraly et al. (2007) and Green and Oram (1983), respectively, and more different ratio $26.52: 55.35: 18.12 \%$ and $17.51: 47.65: 34.84 \%$ by Boschin et al. (2008) and Mierlita (2015), respectively. Among examined accessions SFA constituted $8.3 \%$ and UFA $91.7 \%$. This data are in good agreement with literature values: 10 and $90 \%$ as well as 11.4 and $88.6 \%$ obtained by Hamma and Bhardwaj (2004) and Oomah and Bushuk (1984), respectively. 
Table 4 Unsaturated fatty acids (\% in oil) in fat content and $\omega-3 / \omega-6$ fatty acid ratio in seeds of white lupin represented by: wild lines (CO); landraces (LR); cross derivatives plus mutants (XD) and cultivars (CV)

Fatty acid/accessions

Mean

Minimum

Maximum

Standard deviation (SD)

Oleic acid $\left(\mathrm{C}_{18: 1}\right)$

$\mathrm{CO}$

$\mathrm{LRr}$

$\mathrm{XD}$

$\mathrm{CV}$

$\mathrm{LSD}_{0.05}$

Linoleic acid- $\omega-6\left(\mathrm{C}_{18: 2}\right)$

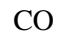

LR

XD

$\mathrm{LSD}_{0.05}$

Linolenic acid- $\omega-3\left(\mathrm{C}_{18: 3}\right)$

Eicosenoic acid $\left(\mathrm{C}_{20: 1}\right)$

Erucic acid $\left(\mathrm{C}_{22: 1}\right)$

$\omega-3 / \omega-6$ fatty acid ratio

Means followed by different letter differ at $\alpha=0.05$
$\mathrm{CO}$

LR

$\mathrm{XD}$

$\mathrm{CV}$

$\mathrm{LSD}_{0.05}$

CO

LR

XD

$\mathrm{CV}$

$\mathrm{LSD}_{0.05}$

$\mathrm{CO}$

LR

XD

$\mathrm{CV}$

$\mathrm{LSD}_{0.05}$

$\mathrm{CO}$

LR

XD

$10.03 a$

$9.88 \mathrm{a}$

$10.14 \mathrm{a}$

$10.25 \mathrm{a}$

0.432

4.362b

$4.495 b$

$4.487 \mathrm{~b}$

4.797a

0.197

$.638 b$

$1.617 \mathrm{~b}$

$1.730 \mathrm{~b}$

$1.994 \mathrm{a}$

0.172

$\mathrm{CV}$

$\mathrm{LSD}_{0.05}$

$0.494 \mathrm{c}$

$0.495 \mathrm{c}$

$0.542 \mathrm{a}$
$55.69 \mathrm{a}$

$55.93 \mathrm{a}$

$55.65 a$

55.61a

0.957

20.29a

20.00ab

$19.31 \mathrm{bc}$

18.91c

0.796

46.9

41.2

50.5

49.3

13.8

13.7

14.8

14.3

\section{6}

6.7

7.9

6.9

1.5

3.1

3.1

3.8

12.5

12.5

12.5

12.8

66.2

3.330

64.6

2.973

2.198

2.637

62.7

27.4

2.728

3.012

1.858

2.251

23.4

(1)

1.641

1.169

0.934

1.205

5.8

0.745

5.8

0.568

5.6

0.499

5.9

0.516

0.21

0.74

0.0804

0.32

0.64

0.0735

0.38

0.79

0.0674

0.38

0.87

0.0917
Higher content of PUFAs represented by linoleic FA $(\omega-6)$ and linolenic FA $(\omega-3)$ are considered desirable for human nutrition. Actually in many countries health organizations promote the intake of foods with increased amounts of $\omega-3$ FA (Simopoulos, 2003). The $\omega-3 / \omega-6$ fatty acid ratio is important for human health and should be 1:1-1:4 whereas in the Western diet it is estimated to be
1:10-1:30 (Schmidt 2001). White lupin seeds for examined classes of accessions meet this desirable ratio criterion (Table 5). Regarding PUFA, the average content of linolenic and linoleic acid was 10.07 and $19.62 \%$ (ratio $1: 2$ ) with a consequent $\omega-3 / \omega-6$ fatty acid ratio on the average level 0.51 and minimum and maximum values in range from 0.21 for the $\mathrm{CO}$ accession from Greece to 0.87 for the $\mathrm{CV}$ from 
Table 5 Saturated (SFA), monounsaturated and polyunsaturated fatty acids (MUFA; PUFA) expressed as \% of total fatty acids and ratio linolenic/linoleic acid $(\omega-3 / \omega-6)$

\begin{tabular}{lccccc}
\hline Accessions & FAT & SFA & MUFA & PUFA & $\omega-3 / \omega-6$ ratio \\
\hline CO & 10.077 & 8.018 & 61.690 & 30.320 & 0.494 \\
LR & 10.227 & 8.070 & 62.042 & 29.880 & 0.495 \\
XD & 9.287 & 8.713 & 61.868 & 29.450 & 0.525 \\
CV & 9.655 & 8.390 & 62.401 & 29.160 & 0.542 \\
Average & 9.811 & 8.297 & 62.000 & 29.702 & 0.514 \\
\hline
\end{tabular}

SFA—sum of percentage values of total saturated fatty acids (FA), i.e. palmitic acid + stearic acid, MUFA—sum of the percentage values of monounsaturated FA, oleic acid + eicosenoic acid + erucic acid, PUFA — sum of percentage values of polyunsaturated $\mathrm{FA}$, i.e. linoleic acid + linolenic acid, $\mathrm{CO}$ - wild lines, LR—-landraces, XD—breeding material (cross derivative and mutants), CVcultivars

Germany. Average ratios for examined classes of accessions shows a narrow range of variability from 0.49 for $\mathrm{CO}$ and LR accessions to 0.54 for $\mathrm{CV}$ accessions (Table 5). Similar, very favourable $\omega-3 /$ $\omega-6$ ratio ranged from 0.49 to 0.79 obtained Boschin et al. (2008) and on another level of 0.27-0.37 Mierlita (2015). Calculated ratios: 0.45 and 0.54 reported Uzun et al. (2007) and Zraly et al. (2007), and for bitter and sweet white lupin seeds 0.42 and 0.33 , respectively (Yorgancilar and Bilgicli 2014). The high value of $\omega-3 / \omega-6$ fatty acid ratio is typical of white lupin, whereas other lupin crops i.e. yellow lupin and narrow-leafed lupin, have lower $\omega-3 / \omega-6$ ratio, due to a much higher linoleic acid content (Boschin et al. 2008). According to data given by Rybiński et al. (2014) seeds of yellow lupin, narrow-leafed lupin and Andean lupin contain high amount of linoleic acid $(51.9,40.5$ and $34.5 \%$, respectively) as compared to white lupin (15.6), what in consequence influences the unfavorable low value of $\omega-3 / \omega-6$ fatty acid ratio $(0.16,0.12$ and 0.10 , respectively). Similar low values for vegetable oils, such as olive oil (0.13), soybean oil (0.15) and walnut oil (0.20) noticed Belitz and Grosch (1999).

Up to here presented results comprised fat content and fatty acid composition considered each of four examined groups of accessions. In respect to all 371 investigated accessions the distribution and frequency of their participation for fat and each fatty acid presents Fig. 2. Independently from examined traits, the figure indicates a broad range of variability of fat and fatty acid in white lupin seeds. From this point of view described collection can be treated as a rich source of variability for analyzed traits and allowed to recognize and select the most desirable accessions for nutritional purposes. A chosen favorable accession may constitute an interesting initial material for breeding new cultivars of white lupin with a high oil quality. Particularly valuable are accessions with the highest oil content and with high content of linolenic acid $(\omega-3)$ and low or zero content of erucic acid. Among all examined accessions sixteen of them contained in seeds the highest fat content (from 12 to $15 \%$ ). Also sixteen accessions were selected, mostly in the CO class, as high $\omega-3$ genotypes with the content excided $12 \%$ (Fig. 2). Valuable lines with high fat and linolenic acid content present Table 6. Unfortunately, the intake of $\omega-3$ fatty acid has declined in developed countries (with increased intake of $\omega-6$ fatty acid). Consumption of foods rich in $\omega-3$ has steadily declined and $\omega-3$ FA constitute only a small portion (below 1\%) of total fatty acids in U.S. food supply (Raper et al. 1992; Watkins 2004). In opposite to desirable selection of high $\omega-3$ FA accessions, a presence in seeds of erucic FA has a negative influence on oil quality in human nutrition. According to results presented in Fig. 2, twenty-five accessions contained erucic FA below 1\%. Majority of low erucic accessions were recognized in CO and LR classes (13 and 8, respectively) but only four and only in $\mathrm{CO}$ class were erucic free accessions. It indicates, that collected wild accessions and landraces may constitute a valuable material for selection of erucic free or low erucic acid genotypes for breeding purposes. Two genotypes classified as "low erucic acid" below of $2 \%$ obtained Boschin et al. (2008).

In order to estimate the relationships for fat and fatty acids content, the correlation coefficient was calculated (Table 7). Statistically significant values were obtained for the most traits. The relationships 

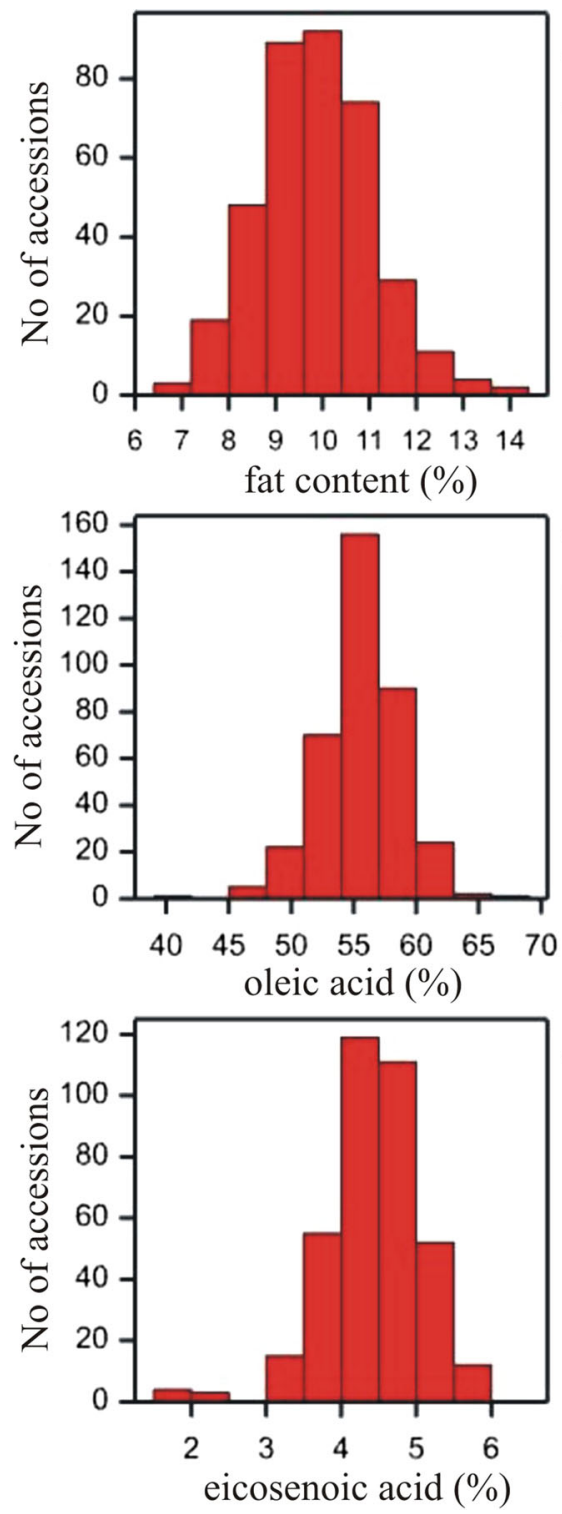

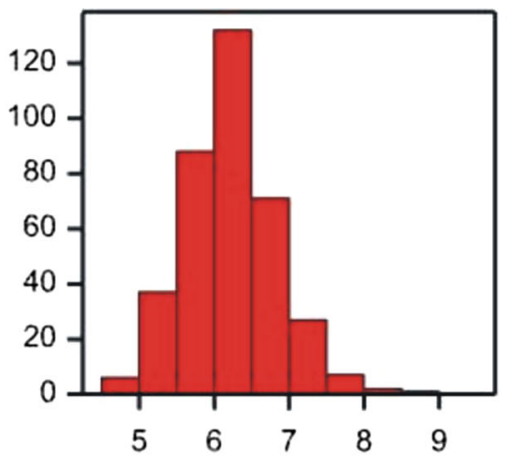

palmitic acid (\%)
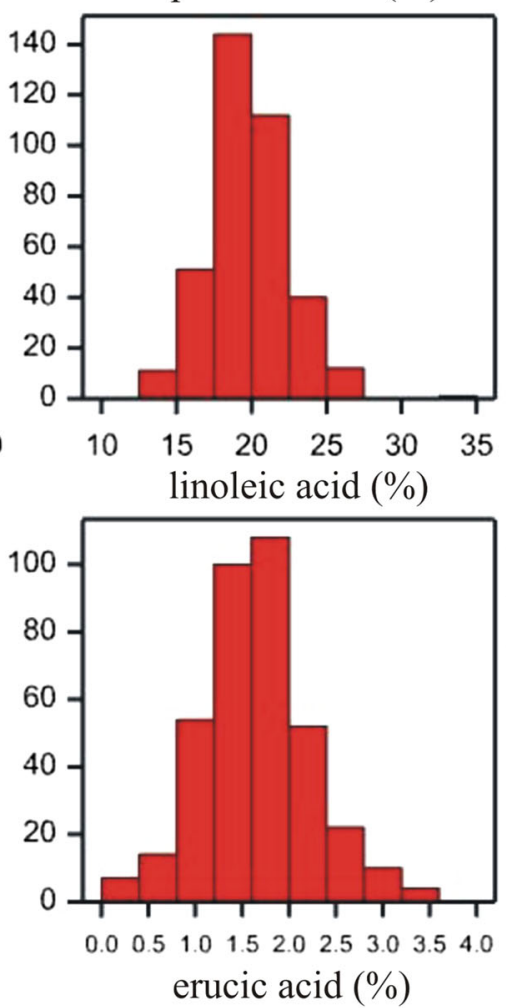
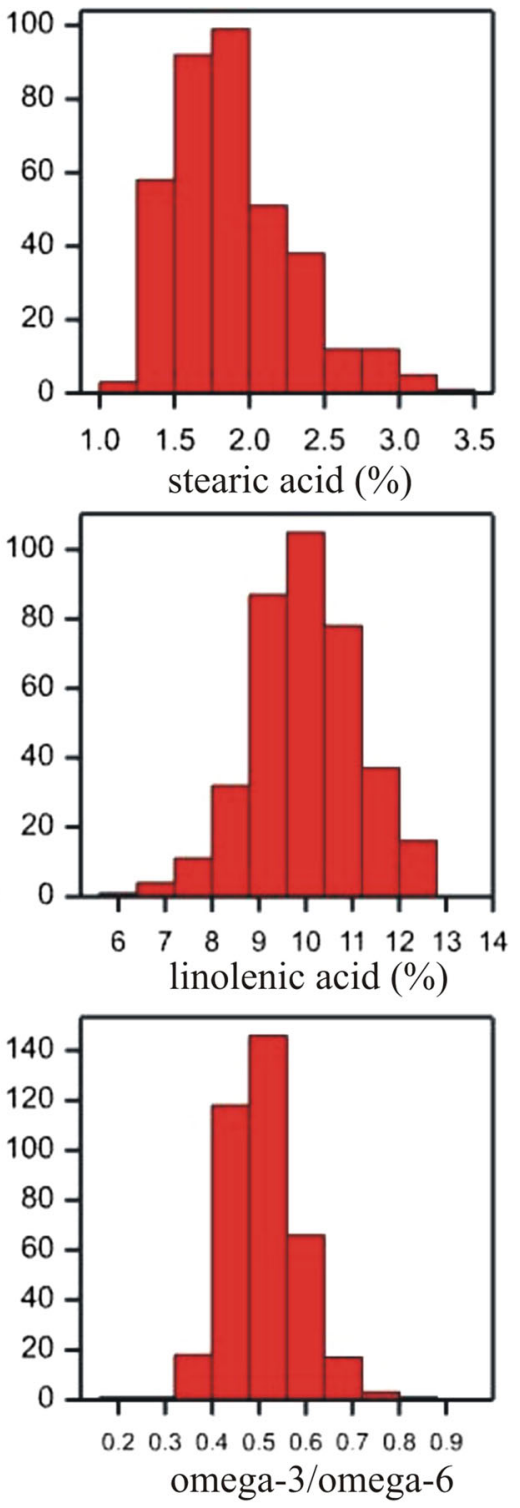

Fig. 2 Quantitative participation of accession for fat (\%) and fatty acids content (\% in oil): palmitic acid, stearic acid, oleic acid, linoleic acid, linolenic acid, eicosenoic acid and erucic acid as well as $\omega-3 / \omega-6$

between fat and first of all UFA content are of considerable interest in human nutrition. In classes of accessions the oil content was positively correlated with stearic and oleic fatty acids and negatively with palmitic, linoleic, linolenic and erucic acid. Only in XD group stearic and linolenic FA were not statistically significant in relationships with fat. According to Jimenez et al. (1991) oil content is strongly negatively correlated with linoleic and linolenic and positively with oleic fatty acid. This is in agreement with ours results. Moreover, oleic acid in each class of accessions showed significant and negative correlations with linoleic and linolenic fatty acid (PUFA). Negative relationship between oleic acid and linoleic fatty acid content observed also Uzun et al. (2007). It may indicate that in selection of high oil genotypes may accompany an increase amount of oleic acid with simultaneously declined of PUFA portion. Undoubtedly, oleic and especially linolenic acid are the dubious zone for white lupin breeders. In opinion of 
Table 6 Selected accessions with high content of fat (g/100 g d.m.) and linolenic acid (\% in oil) in seeds of white lupin

\begin{tabular}{|c|c|c|c|c|c|c|c|}
\hline Class of origin & $\begin{array}{l}\text { Accession } \\
\text { number }\end{array}$ & $\begin{array}{l}\text { Country } \\
\text { of origin }\end{array}$ & Fat & $\begin{array}{l}\text { Class of } \\
\text { origin }\end{array}$ & $\begin{array}{l}\text { Accession } \\
\text { number }\end{array}$ & $\begin{array}{l}\text { Country } \\
\text { of origin }\end{array}$ & $\begin{array}{l}\text { Linolenic } \\
\text { acid }(\omega-3)\end{array}$ \\
\hline \multirow[t]{8}{*}{$\mathrm{CO}$} & Wt 95138 & Spain & 12.1 & \multirow[t]{8}{*}{$\mathrm{CO}$} & Wt 95090 & Greece & 12.1 \\
\hline & Wt 95017 & Spain & 12.3 & & Wt 95139 & Italy & 12.1 \\
\hline & Wt 95083 & Spain & 12.3 & & Wt 95272 & Greece & 12.2 \\
\hline & Wt 95037 & Spain & 12.3 & & Wt 95021 & Portugal & 12.4 \\
\hline & Wt 95067 & Spain & 12.4 & & Wt 95268 & USA & 12.4 \\
\hline & Wt 95009 & Spain & 12.5 & & Wt 95605 & Greece & 12.4 \\
\hline & Wt 95014 & Spain & 12.9 & & Wt 95257 & Marocco & 12.5 \\
\hline & Wt 95038 & Spain & 12.9 & & Wt 95525 & Turkey & 12.5 \\
\hline \multirow[t]{3}{*}{$\mathrm{CV}$} & Wt 95149 & Poland & 12.5 & \multirow[t]{4}{*}{$\mathrm{CV}$} & Wt 95445 & Russia & 12.3 \\
\hline & Wt 95443 & France & 12.6 & & Wt 95093 & Spain & 12.5 \\
\hline & Wt 95429 & Poland & 14.1 & & Wt 95467 & Chile & 12.7 \\
\hline \multirow[t]{5}{*}{ LR } & Wt 95008 & Spain & 12.2 & & Wt 95510 & Germany & 12.8 \\
\hline & Wt 95006 & Spain & 12.5 & \multirow[t]{3}{*}{ LR } & Wt 95086 & Algeria & 12.3 \\
\hline & Wt 95175 & Spain & 13.2 & & Wt 95029 & Spain & 12.4 \\
\hline & Wt 95149 & Spain & 13.3 & & Wt 95088 & Egypt & 12.5 \\
\hline & Wt 95212 & Jordan & 14.1 & $\mathrm{XD}$ & Wt 95180 & Poland & 12.5 \\
\hline
\end{tabular}

$\mathrm{CO}$ —wild lines, LR—-landraces, $\mathrm{XD}$ —breeding material (cross derivative and mutants), $\mathrm{CV}$-cultivars

Jimenez et al. (1991) lower levels of linolenic acid could be combined with high oleic acid and total oil content. Statistically significant and positive relationships between both PUFA were noticed only for CO and LR accessions. In the studied collection a presence of accessions with high $\omega-3 / \omega-6$ fatty acids ratio indicates that this correlation is relatively week and possible to break toward higher content of $\omega-3$ fatty acid.

Undesirable in each class of accessions was a negative correlation between erucic acid and fat content. Negative, although not statistically significant relationship between fat and erucic acid content was found in seeds of common vetch and lupins (Rybiński et al. 2015). It indicates that selection for improvement of fat content must be not connected with increased amount of erucic acid what confirms "low erucic acid" accessions (using a definition applied to rapeseed oil) presented in Table 8. Furthermore erucic acid was significantly and negatively related with oleic fatty acid. However no significant relationships were observed between erucic acid and both PUFA (Table 7).

Estimation of similarity of all accessions in terms of studied traits approached jointly, in spatial form and in the system of the first two main principal variables, is presented in Fig. 3. Both principal variables elucidated $89.22 \%$ of multivariate variability. Majority of genotypes, representing each of four classes of accessions are densely located in central part of figure what indicates their close similarity in terms of fat content and fatty acid profile. Residual accessions are located in more or little extreme position from the middle part of the figure. High yielding and low alkaloid cultivar Butan (treated as reference for remaining accessions) is located in middle-left hand side of the space. The most extreme and separate position of accession indicates their low degree of similarity in the response of studied traits as compared to remaining genotypes. It is interesting that the most separate position are occupied by wild accessions followed by landraces. It is visible in the top and particularly in the right-top part of the figure in opposite to cultivars located mainly in the bottom part of the space. More separate location of the part of $\mathrm{CO}$ and LR accessions indicate their lower similarity to remaining accessions including cultivars. Above mentioned $\mathrm{CO}$ as well as LR accession may constitute valuable sources of fat and fatty acid variability used as initial material for breeding. 
Table 7 Coefficient of correlation for fat and fatty acids for four types of investigated accessions

\begin{tabular}{|c|c|c|c|c|c|c|c|c|}
\hline $\begin{array}{l}\text { Fat and fatty acids and } \\
\text { types of accessions }\end{array}$ & Fat & $\mathrm{C}_{16: 0}^{\mathrm{a}}$ & $\mathrm{C}_{18: 0}$ & $\mathrm{C}_{18: 1}$ & $\mathrm{C}_{18: 2}$ & $\mathrm{C}_{18: 3}$ & $\mathrm{C}_{20: 1}$ & $\mathrm{C}_{22: 1}$ \\
\hline
\end{tabular}

$\mathrm{CO}$

\section{Fat}

$\mathrm{C}_{16: 0}^{\mathrm{a}}$

$\mathrm{C}_{18: 0}$

$\mathrm{C}_{18: 1}$

$\mathrm{C}_{18: 2}$

$\mathrm{C}_{18: 3}$

$\mathrm{C}_{20: 1}$

$\mathrm{C}_{22: 1}$

LR

Fat

$\mathrm{C}_{16: 0}^{\mathrm{a}}$

$\mathrm{C}_{18: 0}$

$\mathrm{C}_{18: 1}$

$\mathrm{C}_{18: 2}$

$\mathrm{C}_{18: 3}$

$\mathrm{C}_{20: 1}$

$\mathrm{C}_{22: 1}$

XD

Fat

$\mathrm{C}_{16: 0}^{\mathrm{a}}$

$\mathrm{C}_{18: 0}$

$\mathrm{C}_{18: 1}$

$\mathrm{C}_{18: 2}$

$\mathrm{C}_{18: 3}$

$\mathrm{C}_{20: 1}$

$\mathrm{C}_{22: 1}$

CV

\section{Fat}

$\mathrm{C}_{16: 0}^{\#}$

$\mathrm{C}_{18: 0}$

$\mathrm{C}_{18: 1}$

$\mathrm{C}_{18: 2}$

$\mathrm{C}_{18: 3}$

$\mathrm{C}_{20: 1}$

$\mathrm{C}_{22: 1}$
1

$$
-0.376^{* * *} \quad 1
$$$$
0.406^{* * *}-0.185^{*} \quad 1
$$$$
0.431 * * * \quad-0.323 * * * \quad 0.446 * * * \quad 1
$$$$
-0.173^{*}
$$$$
0.120
$$$$
-0.415^{* * *}
$$$$
-0.829 * * *
$$$$
-0.504 * * *
$$$$
0.149 *
$$$$
-0.220 * *
$$$$
-0.517 * * *
$$

$-0.129$

0.028

$-0.186^{*}$

$-0.227 * *$

$-0.144$

$-0.468 * * * \quad 0.063$

$$
-0.030
$$$$
0.107
$$

$0.778 * * * \quad 1$

$$
-0.382 * * *
$$

\section{1}

$$
-0.409 * * * \quad 1
$$

$$
\begin{array}{lll}
0.393 * * * & -0.262 * & 1 \\
0.520 * * * & -0.356 * * & 0.478 *
\end{array}
$$$$
\begin{aligned}
& 0.520 * * * \\
& -0.293 *
\end{aligned}
$$

$$
\begin{aligned}
& 0.128 \\
& 0.090
\end{aligned}
$$$$
-0.584 * * *
$$

$$
\begin{array}{rc}
0.478 * * * & 1 \\
-0.375^{* * *} & -0.91
\end{array}
$$

$-0.059$

$$
0.108
$$

$$
\begin{array}{ll}
-0.332 * * & -0.575 * \\
-0.352 * * & -0.013
\end{array}
$$

1

$-0.378 * * *$

$0.348 * *$

$-0.533 * * * \quad-0.340 * *$

$-0.186$

1

$$
1
$$

$$
\begin{aligned}
& -0.543^{* * *} \\
& 0.194
\end{aligned}
$$

1

0.194
$0.428 * *$

$$
0.054
$$$$
-0.333^{*}
$$

$$
\begin{aligned}
& 1 \\
& 0.162
\end{aligned}
$$$$
-0.045
$$$$
-0.064
$$$$
-0.164
$$$$
1
$$$$
-0.658 * * *
$$$$
0.230
$$$$
-0.060
$$$$
-0.810 * * *
$$$$
0.018
$$$$
-0.506 * * *
$$$$
-0.531 * * *
$$

$\begin{array}{rr}0.063 & 0.018 \\ -0.163 & 0.247\end{array}$

0.087

0.158
$-0.275^{*}$

1

$-0.490 * * * \quad-0.292 *$

$-0.021$

$-0.309 * \quad 1$

1

$-0.27 *$
$0.333 * *$

$$
\begin{array}{cr}
0.333 * * & 0.166 \\
0.503 * * * & -0.231 \\
-0.278 * & -0.018 \\
-0.460 * * * & -0.010
\end{array}
$$$$
0.166
$$$$
-0.278 * \quad-0.018
$$$$
0.419 * * * \quad 1
$$$$
-0.442 * * * \quad-0.838 * * * \quad 1
$$$$
-0.208
$$$$
-0.448 * * *
$$$$
-0.391 * * \quad-0.105
$$

$-0.333 * *$

$-0.067$

1

$-0.194 \quad 0.040$

$-0.243$

0.105

$-0.247 \quad 1$

CO—wild lines, LR—landraces, XD—breeding material (cross derivative and mutants), CV—cultivars

${ }^{a}$ Palmitic acid $\left(\mathrm{C}_{16: 0}\right)$, stearic acid $\left(\mathrm{C}_{18: 0}\right)$, oleic acid $\left(\mathrm{C}_{18: 1}\right)$, linoleic acid $\left(\mathrm{C}_{18: 2}\right)$, linolenic acid $\left(\mathrm{C}_{18: 3}\right)$, eicosenoic acid $\left(\mathrm{C}_{20: 1}\right)$, erucic acid $\left(\mathrm{C}_{22: 1}\right)$

$* P<0.05 ; * * P<0.01 ; * * * P<0.001$ 
Table 8 Selected accessions with low erucic fatty acid content (below 1\% of total fatty acid composition) and high fat content (above 11\%)

\begin{tabular}{llllll}
\hline Accession number & Type of accession & $\begin{array}{l}\text { Country } \\
\text { of origin }\end{array}$ & $\begin{array}{l}\text { Erucic fatty } \\
\text { acid }(\%)\end{array}$ & $\begin{array}{l}\text { Fat content } \\
(\%)\end{array}$ & $\begin{array}{l}\text { Linolenic/linoleic fatty } \\
\text { acid ratio }(\omega-3 / \omega-6)\end{array}$ \\
\hline Wt 95224 & CO & Turkey & 0.0 & 11.6 & 0.36 \\
Wt 95523 & CO & Turkey & 0.4 & 11.4 & 0.59 \\
Wt 95017 & CO & Spain & 0.6 & 12.3 & 0.43 \\
Wt 95068 & CO & Spain & 0.8 & 12.0 & 0.63 \\
Wt 95106 & LR & Spain & 0.8 & 11.6 & 0.41 \\
Wt 95166 & LR & Spain & 0.8 & 11.4 & 0.46 \\
Wt 95174 & LR & Spain & 0.8 & 11.8 & 0.43 \\
Wt 95509 & CV & Germany & 0.7 & 9.8 & 0.53 \\
All studied accessions & CO; LR; XD; CV & - & 1.70 & 0.51 \\
\hline
\end{tabular}

$\mathrm{CO}$ —wild lines, LR—landraces, $\mathrm{XD}$ —breeding material (cross derivative and mutants), $\mathrm{CV}$ —cultivars

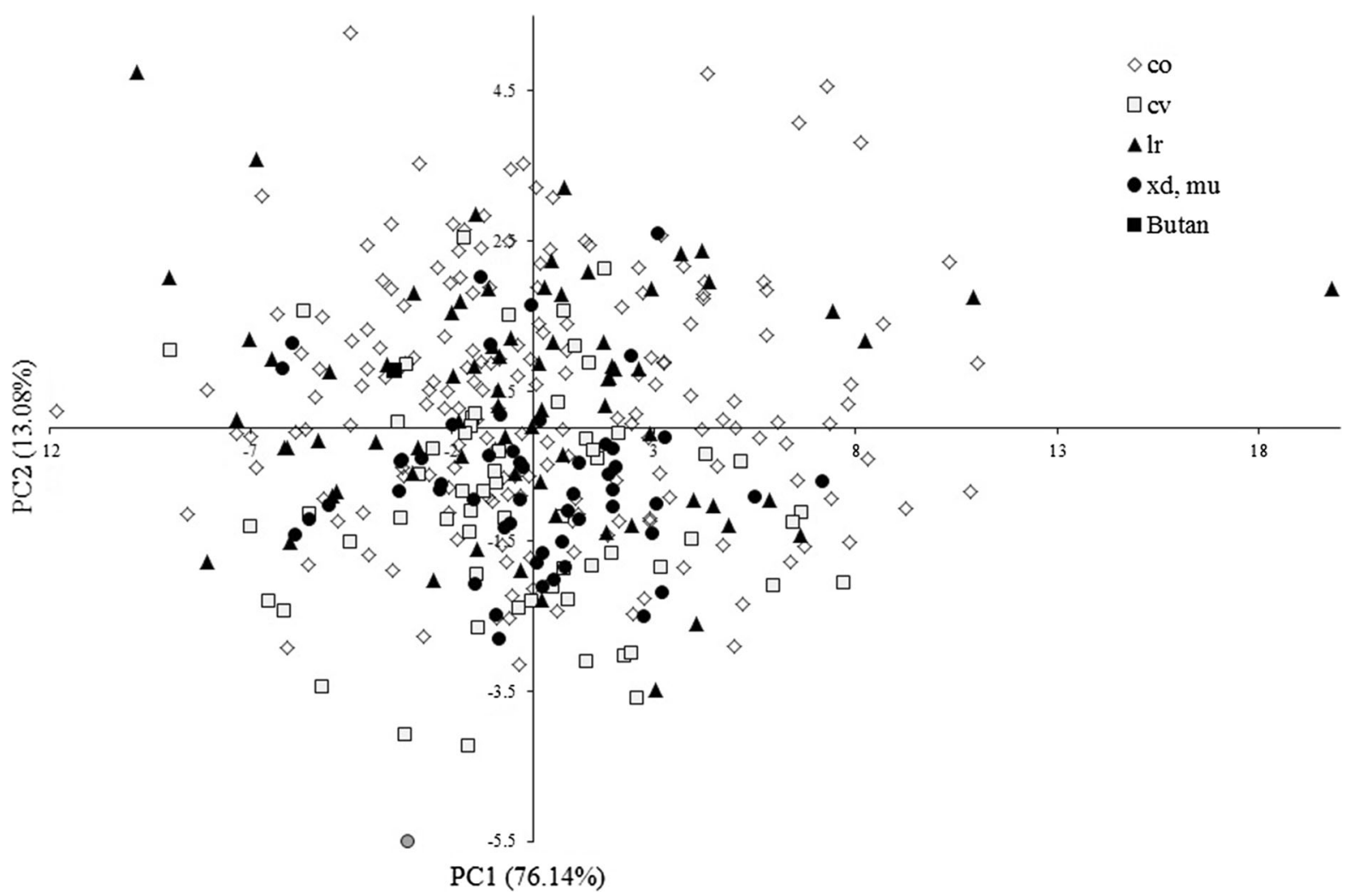

Fig. 3 Distribution of white lupin accessions in the space of two main principal variables for fat content and fatty acid profile combined; $\mathrm{CO}$ — wild lines; LR—landraces; XD—cross derivative and mutants; CV—cultivars; Butan—Polish new cultivar

Nutritional remarks

The large-seeded, bitter white lupin landraces before consumption on local scale as a snack, were boiled and soaked in brine for several washes to remove most of the alkaloids (Cowling et al. 1998). Since the selection of the first sweet white lupin cultivars in the middle of 20-ties century, their seeds have slowly made inroads into modern food industry. White lupin green seeds compete well with green peas, vegetable faba bean and 
soybean seeds. Obtained results indicate that white lupin green seeds may have potential as human food (Bhardwaj and Hamma 2013). A positive use of white lupin seeds for bulgur production obtained in processes of cleaning, soaking, drying and classification was reported by Yorgancilar and Bilgicli (2014) and a possible use in bakery by Kohajdova et al. (2011) for lupin bread and lupin biscuits production. Lupin food products such as lupin pasta and sprouts are now available commercially in Australia. Moreover, lupin seeds as a high-quality alternative to soybean are used for production of fermented food such as Indonesian tempe, Japanese miso and natto, and fermented sauces (Petterson et al. 1997; Petterson 1998). Actually, considering the favourable content of nutrients several companies in Europe have started to produce and commercialise food using lupin seeds (Boschin et al. 2008) as for example for obtaining protein-enriched spaghetti (Doxastakis et al. 2006), muffins biscuits and extrude snacks (Bez et al. 2005) and production of lupin beverages (Seger and Bez, 2005). The value of lupins as feed for monogastric and ruminant animals is well known, also (Cowling et al. 1998). According to data given by Zraly et al. (2007) animal protein or soy in the diet for market pigs may be completely replaced with white lupin seeds with beneficial effect on pork fatty acids composition. A positive effect of white lupin seeds in broiler diet in respect of fatty acid profile of their meat reported Mierlita (2015).

\section{Conclusions}

1. Analysis of the Polish white lupin collection presents a broad range of variability in term of fat content and fatty acid composition. It allowed to recognize accessions with high fat content among wild material, landraces, cultivars and cross derivatives.

2. No evident differences in term of average fat and fatty acid content among examined accession classes were observed. Range of fat and fatty acid variability within each class of accessions was more visible. It was particularly true for broader fat content variation within cultivars and landraces.

3. The dominating fatty acid in all examined classes was monounsaturated oleic acid (55.7\%). Among polyunsaturated fatty acids dominated linoleic FA
(19.6\%) followed by linolenic FA $(10,1 \%)$. In terms of UFA content the broadest range was noticed for CO and LR (oleic FA), LR (linoleic) and CO (linolenic). Only in the CO class "zero erucic" genotypes were found.

4. Saturated FA constituted only about $9 \%$ of total FA content. Among remained unsaturated FA $30 \%$ of them belong to essential PUFA, represented by linoleic and linolenic FA. This indicates on accessions with high oil quality.

5. The high number of accessions with particularly valuable essential linolenic acid content $(\omega-3)$ was detected in the wild lines. It allows to select accessions with most valuable $\omega-3 / \omega-6$ ratio.

6. The use of estimated accessions for breeding purposes focused on improvement of fat and fatty acid composition may be partially limited by relationships among studied traits. Fortunately an absence of significant correlation among part of studied traits makes their simultaneous improvement in one genotype feasible.

\section{Compliance with ethical standards}

Conflict of interest The authors declare that they have no conflict of interest.

Ethical approval This article does not contain any studies with human participants or animals performed by any of the authors.

Open Access This article is distributed under the terms of the Creative Commons Attribution 4.0 International License (http:// creativecommons.org/licenses/by/4.0/), which permits unrestricted use, distribution, and reproduction in any medium, provided you give appropriate credit to the original author(s) and the source, provide a link to the Creative Commons license, and indicate if changes were made.

\section{References}

Adomas B, Piotrowicz-Cieślak AI (2010) Oil and fatty acid accumulation in maturing yellow lupin seeds (in Polish). Zesz Probl Post Nauk Rol 550:43-51

Belitz HD, Grosch W (eds) (1999) Legumes. In: Chemistry food. Springer, Berlin, pp 694-715

Bez J, Shott M, Seger A (2005) Application of lupin protein ingredients in muffins, biscuits and extruded snacks. In: Arnoldi A (ed) Optimised processing for preparing healthy and added value food ingredients from lupin kernel, the European protein rich grain legume. Roma, ARCANE Editrice, pp 51-66 
Bhardwaj HL (2002) Evaluation of lupin as a new food/feed crop in the US Mid-Atlantic region. In: Janick J, Whipkey A (eds) Trends in new crops and new uses. ASHS Press, Alexandria, pp 115-119

Bhardwaj HL, Hamma AA (2013) Cultivar and growing location effects on fatty acids, minerals, and sugar in green seeds of white lupin (Lupinus albus L.). Open Hortic J $6: 1-8$

Bhardwaj HL, Hamma AA, Merrick LC (1998) Genotypic and environmental effects of lupin seed composition. Plant Foods Hum Nutr 53:1-13

Boschin GD, D’Agostina A, Annicchaiarico P, Arnoldi A (2007) The fatty acidd composition of the from Lupinus albus as affected by environmental and agricultural factors. Eur Food Res Technol 225:769-776

Boschin G, D'Agostina A, Annicchaiarico P, Arnoldi A (2008) Effect of genotype and environment on fatty acid composition of Lupinus albus L. seed. Food Chem 108:600-606

Codex Alimentarius (2001) Codex standard for named vegetable oils. CX-STAN 8:210-1999

Cowling WA, Tarr A (2004) Effect of genotype and environment on seed quality in sweet narrow-leafed lupin (Lupinus angustifolius L.). Aust J Agric Res 55(7):745-751

Cowling WA, Buirchell BJ, Tapia ME (1998) Lupin, Lupinus L. Promoting the conservation and use of underutilized and neglected crops. 23. Institute of Plant Genetics and Crop Plant Research, Gatersleben/International Plant Genetics Resources Institute, Rome

De Cortes-Sanchez M, Altares P, Prdrosa MM, Burbano C, Cuadrado C, Goyoaga G, Muzquiz M, Jimenez-Martinez C, Davila-Ortiz G (2005) Alkaloid variation during germination in different lupin species. Food Chem 90:347-355

Doxastakis G, Papageorgiou M, Mandalou D, Irakli M, Papalamprpu E, D'Agostina A (2006) Technological properties and non-enzymatic browning of Lupinus albus protein-enriched spaghetti. Food Chem 101:57-64

El-Adawy TA, Rahma EH, El-Badawey AA, Gafar AF (2001) Nutritional potential and functional properties of sweet and bitter lupin seed protein isolates. Food Chem 14:455-462

Erbas M, Certel M, Uslu MK (2005) Some chemical properties of white lupin seeds (Lupinus albus L.). Food Chem 89:341-345

Francki MG, Whitaker P, Smith PM, Atkins CA (2002) Differential expression of a novel gene during seed triacylglycerol accumulation in lupin seeds species (Lupinus angustifolius L. and Lupinus mutabilis L.). Funct Integr Genomics 2:292-300

Gladstones JS (1970) Lupin as a crop plants. Field Crop Abstr 23:123-148

Gladstones JS (1998) Distribution, origin, taxonomy, history and importance. In: Gladstones JS, Atkins CA, Hambia J (eds) Lupines as a crop plants biology, production and utilization. CAB International, Wallingford, pp 1-39

Green AG, Oram RN (1983) Variability for protein and oil quality in Lupinus albus. Anim Feed Sci Technol 9(4):271-282

Gulewicz R, Martinez-Villaluenga C, Frias J, Ciesiołka D, Gulewicz K, Vidal-Valverde C (2008) Effect of germination on the protein fraction-composition of different lupin seeds. Food Chem 107:830-844
Hamma AA, Bhardwaj HL (2004) Phytosterols, triterpene alcohols, and phospholipids in seed oil from white lupine. J Am Oil Chem Soc 81:1039-1044

Hondelmann W (1984) The lupin-ancient and modern crop plant. Theor Appl Genet 68:1-9

Jansen PCM (2006) Record from Protabase. In: Brink M, Belay G (eds) Plant Resources of Tropical Africa. PROTA, Wageningen

Jimenez MD, Cubero JI, De Haro A (1991) Genetic and environmental variability in protein, oil and fatty acids in high alkaloid white lupin (Lupinus albus L.). J Sci Food Agric 55:27-35

Kohajdova Z, Karovicova J, Schmidt S (2011) Lupin composition and possible use in bakery - a review. Czech J Food Sci 29(2):203-211

Kurlovich BS (2002) Lupins (Geography, classification, genetic resources and breeding). OY International North Express, St. Petersburg, p 468

Martinez-Villaluenga C, Frias J, Vidal-Valverde C (2006) Functional lupin seeds (Lupinus albus L. and Lupinus luteus L.) after extraction of a $\alpha$-galactosides. Food Chem 98:291-299

Mierlita D (2015) The effect of lupin seed in broiler diet on animal performance and fatty acids profile of their meat. Bull UASVM Anim Sci Biotechnol 72(2):188-193

Mohamed AA, Rayas-Duarte P (1995) Composition of Lupinus albus. Cereal Chem 72:643-647

Mülayim M, Tamkoc A, Babaoglu M (2002) Sweet white lupins versus local bitter genotype: agronomic characteristics as affected by different planting densities in the Göller region of Turkey. Eur J Agron 17:181-189

Nigussie Z (2012) Contribution of white lupin (Lupinus albus L.) for food security in North-Western Ethiopia: a review. Asian J Plant Sci 11(5):205-212

Oomah B, Bushuk W (1984) Chemical changes in developing lupin seed. Plant Foods Hum Nutr 34:221-228

Petterson DS (1998) Composition and food uses of lupin. In: Gladstones JS, Atkins CA, Hamblin J (eds) Lupin as a crop plants biology, production and utilization. CAB International, Wallingford, pp 353-379

Petterson DS, Mackintosh JB (1994) The chemical composition and nutritive value of Australian grain legumes. Grain Research and Development Corporation, Canberra

Petterson DS, Sipsas S, Mackintosh JB (1997) The chemical composition and nutritive value of Australian grain legumes, 2nd edn. Grain Research and Development Corporation, Canberra

Raper NR, Cronin FJ, Exler J (1992) Omega3 fatty acid content of the US food supply. J Am Coll Nutr 11(3):304-308

Reinhard H, Rupp H, Streule M, Zoller O (2006) Quinolizidine alkaloids and phomopsins in lupin seeds and lupin containing food. J Chromatogr A 1112:303-360

Rochfort S, Panozzo J (2007) Phytochemicals for health, the role of pulses. J Agric Food Chem 55:7981-7994

Roth-Maier DA, Kirchgessner M (1993) Nutrient composition and nutritive value of white and yellow lupins (Lupinus albus L. and Lupinus luteus L.) for pigs and poultry. Agribiol Res 46:218-228

Ryan E, Galvin K, O'Connor TP, Maguire AR, O'Brien NM (2007) Phytosterol, squalene, tocopherol content and fatty 
acid and profile selected seeds, grains, and legume. Plant Foods Hum Nutr 62:85-91

Rybiński W, Starzycki M, Rusinek R, Bocianowski J, Szot B (2013) Variation of legumes seed's chemical composition and resistance to mechanical damage (in Polish). Biuletyn IHAR 268:193-209

Rybiński W, Rusinek R, Szot B, Bocianowski J, Starzycki M (2014) Analysis of interspecies physicochemical variation of grain legumes seeds. Int Agrophys 28:491-500

Rybiński W, Bańda M, Bocianowski J, Börner A, Starzycki M, Szot B (2015) Estimation of mechanical properties of seeds of common vetch accessions (Vicia sativa L.). Genet Resour Crop Evol 62:361-375

Schmidt MA (2001) Brain-building nutrition, the healing power for fats and oils, 2nd edn. North Atlantic Books, Berkeley

Seger A, Bez J (2005) Production of lupin beverages. In: Arnoldi A (ed) Optimised processing for preparing healthy and added value food ingredients from lupin kernel, the European protein rich grain legume. Roma, ARACNE Editrice, pp 67-76

Simopoulos AP (2003) Importance of the ratio of omega-6/ omega-3 essential fatty acids: evolutionary aspects. World Rev Nutr Diet 92:1-22

Smulikowska S, Wasilewko J, Mieczkowska A (1995) A note on the chemical composition of the cotyledons and seed coat of three species of sweet lupin. J Anim Feed Sci 4:69-76
Suchy P, Strakova E, Kroupa L, Vecerek V (2008) The fatty acid content of oil from seeds of some lupin varieties. In: Palta JA, Berger JB (eds) Lupin for health and wealth. International lupin conference 14-18 Sept. 2008, Fremantle, Western Australia. International Lupin Association, Canterbury, New Zealand. ISBN 0-86476-153-8

Sujak A, Kotlarz A, Strobel W (2006) Composition and nutritional evaluation of several lupin seeds. Food Chem 98:711-719

Święcicki W, Kroc M, Kamel K (2015) Lupins. In: De Ron AM (ed) Grain legumes. Handbook of plant breeding, vol 10. Springer, New York, pp 179-218

Tizazu H, Emire SA (2010) Chemical composition, physicochemical and functional properties of lupin (Lupinus albus) seeds grown in Ethiopia. Afr J Food Agric Nutr Dev 10:3029-3046

Uzun B, Arslan C, Karhan M, Toker C (2007) Fat and fatty acids of white lupin (Lupinus albus L.) in comparison to sesame (Sesamum indicum L.). Food Chem 102:45-49

Watkins C (2004) Fundamental fats. Inform 15(10):638-640

Yorgancilar M, Bilgicli N (2014) Chemical and nutritional changes in bitter and sweet lupin seed (Lupinus albus L.) during bulgur production. J Food Sci Technol 51(7):1384-1389

Zraly Z, Pisarikova B, Trckova M, Herzig I, Juzi M (2007) The effect of white lupine on the performance, health, carcass characteristics and meat quality of market pigs. Vet Med 52(1):29-41 